\title{
Impacts of multimedia gloss on Learning Reading Comprehension in ESL context
}

Dr Habibullah Pathan, Director and Associate Professor, ELDC, Mehran University of Engineering and
Technology Jamshoro, Pakistan Sahib Khatoon, Assistant Professor, ELDC, Mehran University of Engineering and Technology Jamshoro, Pakistan

Dr Shumaila Aijaz Memon, Associate Professor, ELDC, Mehran University of Engineering and Technology Jamshoro, Pakistan

Dr Muhammad Arslan Raheem, Assistant Professor, University of Education, Pakistan.

Dr Fatima Dar, Director, Centre for Teaching Excellence \& Learning Innovation Iqra University, Karachi, Pakistan

Faiza Mushtaq, Lecturer, National University of Modern Languages, Multan, Pakistan

\begin{abstract}
With the expansion of education, and technology-mediated tools, the technology mediatedcourses are taking high response in teaching and learning by attracting learners' attention, particularly in the reading skills context. Henceforth, the current study's objectives were to know the effects of multimedia glossing in helping engineering students reading comprehension and to know which multimedia features remained the strong factors in enhancing reading comprehension of the engineering students of Mehran UET Jamshoro, Pakistan. Two research tools were used to collect the data from 20 engineering students studying in the first-year first semester of engineering university in Pakistan, and an action research design was followed to accomplish the aim of the research. The sample of the study was selected through the judgment sampling technique. The data collected from the test and analysed on SPSS. The qualitative data collected through the semi-structured interview and analysed through thematic analysis. The findings of the study demonstrated that the employment of multimedia glossing in the ESL reading comprehension class proved useful which scaffolded the process of texts' understanding effectively. In contrast, the audio feature remained the least effective in helping engineering students comprehending the information as compared to audio glossing and image multimedia features. Therefore, one of the suggestions of the research is for teachers and university administration is to plan a multimedia integrated lessons/ modules/ program with a proper guideline to conduct English language classes. Besides that, the university community should incorporate multimedia glossing according to the need of the learners, learning, and context in their lessons as it will let them visualize difficult abstract information without difficulty.
\end{abstract}

Keywords: ESL engineering students, multimedia features, reading comprehension, technology-mediated programs.

$\begin{array}{lll}\text { Received: 04.12.2020 } & \text { Accepted: 18.01.2021 } & \text { Published: 04.02.2021 }\end{array}$

\section{INTRODUCTION}

Pakistani education has not shown incredible development the existing syllabus for engineering students is not appropriate according to their needs, and they are forcefully taught that syllabus which they never enjoy. Engineering students lack reading comprehension, there can be many reasons behind this lacking; such as they are exposed to the dual system of education ( private/ and public educational institutes), in private institutes English medium instruction whereas in public institutes Urdu medium instruction is prevailing which leads to poor language proficiency (Nawab, 2012; Mahboob, 2017). Along with these factors, there were multiple other factors too which can be the cause of students' low level of language skills especially reading skills (Kakepoto et al., 2012). Henceforward, a novel instruction is needed to compensate for the loophole. Thus, everyone is trying hard to improve the educational system by integrating technology in teaching and learning language education in the ESL context. The practice of technology- integration in teaching language has become an innovative trend among Pakistani educators. Technology-mediated devices, the internet, and social media have become a trend for the new generation trend and they are known as tech-savvy (Subaidi and Punan, 2020; Yunus et al., 2020).

Reading comprehension skill is ever discussed in the researches. According to (Wahab et al., 2017), multiple factors become the reason for lacking reading comprehensions such as their parents' 
educational background, low self-confidence, and lack of general knowledge. Thus, the visual simulation was supposed to be a practical technique to enhance the reading comprehension of the engineering students. Though Pakistan is at the initial stage of technology integration in educational institutes but to help the students to be familiar with current trends of global education (Hilmi and Hamzah, 2020) there must be designers and teachers keep abreast with the world. According to (Karthigesu et al., 2020; Rafiq and Hashim, 2018) the educators and policymakers are also aware of the status of technical assistance in an educational context, particularly for low proficient readers' enhancement of the proficiency in reading comprehension.

A plethora of research is carried on the practice of technology in the ESL context and these have confirmed the encouraging outcomes for ESL learners (Bani-hamad and Abdullah, 2020). It is also verified from the researches that, stimulating features offered by technology-mediated programs are providing much guidance to the learners to visualize the information through visualisation which boosts learners' confidence also to learn language specifically reading skill (Wang and Li, 2019; Dedo et al., 2020; Subaidi and Punan, 2020; Subaidi and Aziz, 2020).

Regardless of the rise of technology in the Pakistani education system, the study or research of the technology-mediated programs or technology integrated classes in the ESL context of Pakistan is rarely seen. Yet the technology integrated programs are at their initial stage of designing and conducting classes in the ESL context (Alsofyani, 2019). The reason for this lacking are many such as; inadequate resources, untrained teachers in technology integration, and having no good internet connection (Farhat and Dzakiria, 2017). Thus, there is a need to integrate multimedia, technology in the ESL context and find its outcomes also, because students of the current era are very much into technology and they love to learn with technology-mediated programs. This thought has risen the need to find the effects of multimedia glossings on engineering students' reading comprehension.

To several Pakistani English teachers, teaching college English writing in Pakistan is a challenging challenge, as it requires not only good language skills among the teachers themselves, but also professional writing instruction (Hassan, A., Kazi, A.S., Shafqat, A., Ahmed, Z., 2020).

Consequently, lack of reading comprehension and multimedia glossing are investigated together by following the cognitive theory of multimedia learning. The cognitive theory of learning with multimedia learning has been discussed by Richard E. Mayer explaining the procedure of comprehension in the human brain that comprehension occurs when a person shape-up the mental representations from words and pictures (Mayer \& Mayer, 2010). Usually, the theory reports how the instructors construct their multimedia instructional activities and use additional effective cognitive strategies to support students to develop reading skills, and comprehend the text efficiently. Another theory that also supports the multimedia integration into ESL context is dual coding theory, this theory describes how the human mind processes information by blending verbal and nonverbal representations such as photos and words (Paivio, 1999). Thus, by blending both theories and exploring the effect of multimedia learning in teaching reading comprehension of engineering ESL students in Mehran UET Jamshoro, Pakistan, and the effect of multimedia glossing on students' reading comprehension performance are the main objectives to investigate in the current study.

\section{The literature of related studies}

\section{Reading Comprehension process}

Learners' readiness for reading or comprehending the text is usually based on the interesting content and the reader's eagerness and motivation towards reading. Therefore, the reading materials must enable the learners' curiosity, excitement, and eagerness to read independently. Besides, the content must influence the reader's reading performance and attitude (Asher et al., 1978). Thus, researchers have made numerous theories and models to explain the reading procedure of understanding reading comprehension and the procedures involved. Understanding or comprehending the material is a cognitive procedure that the reader performs in interpreting the information using a bottom-up, topdown, or interactive model (LaBerge and Samuels, 1974).

In the history of Pakistani colleges and universities, where exposure to English is typically restricted to four hours a week, students may not receive an English writing

lesson (Hassan, A., Kazi, A.S., Shafqat, A., Ahmed, Z., 2020).

Above and beyond that, comprehension also is associated with memorization of the reader. According to (Carroll, 1971) there are numerous techniques or approaches to know about comprehension development, and one of them is the imitation of the information in other structures. If readers have good memorization skills, then higher the chances for the readers to replicate the 
information in other structures. Memorization of the information can be supported through appropriate verbal and image stimuli.

\section{Multimedia Glosses in ESL Education}

The arrival of computer technology proclaimed a paradigm shift in ELT, and teachers and designers of ELT programs have begun to disseminate language lessons by these glosses along with verbal lectures (K, 2020). Multimedia glosses are defined as computer-integrated resources including, images, audio, videos, graphics, animation on one platform as synchronized presentation. Technology- integration in the ESL classroom is thoroughly linked with the term multimedia learning, and the progress of technology has made it easier and more convenient. Over-all, the term "multimedia" is employed to show any sort of action or application which uses a variety of media (video, animation, and many more) for demonstrating the information (Berk, 2009). This integrated single synchronized platform assists the learners' cognitive learning process $(\mathrm{K}, 2020)$.

Research and development sector needs to be strengthened and used for education sector in general and ESL/EFL in particular (Us Saqlain, N., Shafqat, A., Hassan, A., 2020). The method to use multimedia glosses explains that the learners are exposed to the use of visual and audio aids, pictures, animation, and technology during reading comprehension courses (Moreno and Mayer, 1997). Two components comprise the procedure of reading comprehension, one is vocabulary knowledge and text comprehension. Also, multimedia glosses could be utilized to support the students in using their prior knowledge and innovative vocabulary to understand the text. Besides, the numerous components in multimedia glosses could contribute to the learning course of reading and can boost their interest, and enthusiasm to learn more. The employment of multimedia glosses in text comprehension enables readers to improve memory retention, learning fulfilment (Chiou et al., 2015). Thus, multimedia glosses should be used by English language instructors in ESL classes (Ahmad Nasaruddin and Mohd Kamalludeen, 2020). These applications in the ESL learning context offer a more representative picture of L2. Multimedia features make learning more comprehensible.

\section{Mayer's Multimedia learning model}

The multimedia model created by Mayer defines its assistance in the learning process with five principles of multimedia design ( Mayer, 1997). The five principles are:

1. Modality: It shows the benefits of demonstrating information by two modes, such as the combination of words and images or animation and audio narration, through the modality principle learners can enhance higher-order thinking skills by comprehending the complex materials (Fiorella et al., 2012). According to (Heo and Toomey, 2020) animated multimedia modalities produce more positive learning outcomes.

2. Contiguity: According to this principle, the mode of demonstration of the glosses should not be presented separately, but it should be kept closed to make them related to each other (Subaidi and Aziz, 2020). For instance, the description of cloud development using image and audio is better demonstrated all simultaneously to ensure learners can link to both modes of presentation.

3. The split-attention principle: This principle proposes words can be better presented in the auditory method than in text (Liu et al., 2012).

4. Variances: The fourth principle states, individuals have variances, and the influence of contiguity and split attention varies among individuals. According to the CTML, the learners with high-level prior knowledge will be capable of creating their mental image, thus, contiguity is not recommended for them. On the other hand, learners with a low level of prior knowledge may get benefit from contiguity and split attention.

5. Coherence: This principle talks about the shortcomings of surplus information in learning. The materials presented in multimedia learning must avoid utilizing too many words and images. Instead, use rational and important words and images to foster learners' understanding (Mayer et al., 2001).

\section{Blend of two theories: Multimedia Learning Theory and Dual Coding Theory in Reading Comprehension}

The cognitive theory of multimedia learning talks about the procedure of comprehension with the assistance of many media glosses. The psychological characteristic of the cognitive theory of multimedia learning (CTML) assumes that learners choose to build meaningful associations between words and pictures through these glosses learners learn a lot more profoundly than the use of words or pictures exclusively while reading text (Kirschner et al., 2017). One of the principles of (CTML) targets 
that, multimedia instruction is to promote the learner's logical and reasonable mental representation ability. The learner constructs innovative information as an active contributor eventually. The learners may visualize and assume the information by making mental images and become able to comprehend the text better by using multimedia glosses.

Besides, the dual coding theory (DCT) by Allan Paivio discusses the significance of two mental processing, which are verbal and non-verbal processing (Clark and Paivio, 1991). Cognitive and learning processing are the two problems investigated by the researcher to maximize the potential of successful learning and enhancing mental ability by processing information. The dual coding theory highlighted the significance of visual signals in the learning as the human brain can decode the information, which it receives by connecting the verbal and visual signals (Paivio, 1999). As discussed by the dual coding principle, the human brain working memory has two partly self-regulating processors for visual and auditory information. Thus, the cognitive load can be shared between the two processors rather than overload the visual processor. Moreover, too much text for reading results in split attention between listening to the instructor and reading the text (Khalil and Elkhider, 2021).

A thought of multimedia learning is thoroughly associated with the dual coding theory, as both theories emphasize the advantages of the human mind's dual function as an assistant to the cognitive procedure of reading comprehension. Several researchers illustrate a promising outcome in their researches by integrating dual coding theory in reading comprehension. The study conducted by (Wang and $\mathrm{Li}, 2019$ ), revealed that learners with imagery deficit were able to recall and remember the words or information better with the assistance of multimedia glosses, along with that the research found that, imagery-deficit learners were facing problems in reading comprehension due to their slow and lack of imagination power they were unable to create a mental image, but with the multimedia glosses' application students were able to relate the words and pictures and the learners' performance in reading comprehension was enhanced.

The association between multimedia and dual coding theory is verified through the research carried by (Mayer and Moreno, 1996) it was discovered in the study that, a split- attention in multimedia link with the dual-coding theory, and learners who received the treatment with dual stimulus displayed better performance than control group learners who were learning through only one stimulus. Thus, the blend of words and image boost readers understanding by ensuring the reader could generate a mental image and connect with the text.

\section{METHODOLOGY}

\section{Research Design and Research Questions}

The idea of action research, as described by (Altrichter et al., 2005), is followed in the current study. The current study employed five cycles of study by applying diverse multimedia glosses to explore the effects of each gloss in multimedia learning of reading comprehension. There were two main objectives of the study:

1. To investigate whether multimedia learning can be effective in enhancing reading comprehension of engineering students' ESL context.

2. To investigate which multimedia gloss is more effective in helping the reading comprehension process of engineering students in an ESL context.

\section{Participants and instruments of the study}

As the study was conducted in Mehran UET Jamshoro, Pakistan so the participants were first-year students of engineering candidature. Purposive sampling was used, and twenty students were selected based on their level of proficiency and reading fluency ability.

The researcher of the study used two tools for collecting the data for the study, i.e. pre-test and post-test and semi-structured interviews were conducted. The test in the form of a worksheet and has consisted of 20 questions with four reading passages testing their comprehension skills. However, the semi-structured interviews were conducted to explore the students' perceptions of multimedia glosses in learning reading comprehension skills.

\section{Procedures}

A pre-test was given to the engineering students prior to administering the intervention to assess their reading comprehension skills. Every week, the students were taught by using three glossing of multimedia: audio, images, and audio, to test each gloss's effect on students' reading comprehension skills. Finally, the students were taught by using a blend of all three media glossing, as described in multimedia learning earlier. Then, the post-test was administered to assess the multimedia learning's 
impacts in enhancing engineering students' reading comprehension skills. Lastly, the semi-structured interviews were conducted with the participants of the study to know their perceptions vis-a-vis infusion of multimedia learning and multimedia glossing in reading comprehension programs.

\section{Data Analysis}

The quantitative data was analysed by using SPSS-26 software by comparing the mean scores collected through pre-test and post-test. The qualitative data collected through semi-structured interviews were analysed by thematic analysis.

\section{FINDINGS}

\section{First Research objective}

To investigate whether multimedia learning can be effective in enhancing the reading comprehension of engineering students in the ESL context.

Table 1. Pre-test and post-test score

\begin{tabular}{|c|c|c|c|}
\hline No of Students & Pre-test & Post-test & Difference \\
\hline 1 & 2 & 8 & 6 \\
\hline 2 & 3 & 8 & 5 \\
\hline 3 & 3 & 8 & 5 \\
\hline 4 & 3 & 7 & 4 \\
\hline 5 & 3 & 8 & 5 \\
\hline 6 & 3 & 8 & 5 \\
\hline 7 & 3 & 8 & 5 \\
\hline 8 & 3 & 8 & 5 \\
\hline 9 & 2 & 8 & 6 \\
\hline 10 & 2 & 8 & 6 \\
\hline 11 & 3 & 8 & 5 \\
\hline 12 & 2 & 8 & 6 \\
\hline 13 & 4 & 8 & 4 \\
\hline 14 & 4 & 7 & 3 \\
\hline 15 & 3 & 7 & 4 \\
\hline 16 & 4 & 8 & 4 \\
\hline 17 & 3 & 7 & 4 \\
\hline 18 & 3 & 8 & 5 \\
\hline 19 & 3 & 7 & 4 \\
\hline 20 & 2 & 7 & 5 \\
\hline Overall Mean Score & 2.90 & 7.64 & 4.75 \\
\hline
\end{tabular}

Table 1 is showing that there is an increase in the mean scores of the pre-test (2.90) to post-test (7.65). It presented the results of engineering students' reading comprehension skills in answering the comprehension texts prior to use multimedia glossing in the pre-test and after using multimedia glossing in the post-test. The mean scores are clearly showing the considerable increase difference (4.750) after the intervention applied by multimedia glossing in teaching reading comprehension.

Table 2. Paired sample test: Multimedia glossing employment in teaching reading comprehension

\begin{tabular}{|l|l|l|l|l|l|l|}
\hline Reading comprehension & Mean & $\begin{array}{l}\text { Std. } \\
\text { Deviation }\end{array}$ & $\begin{array}{l}\text { Std. } \\
\text { Error } \\
\text { Mean }\end{array}$ & $\boldsymbol{t}$ & $\boldsymbol{d f}$ & $\begin{array}{l}\text { Sig. (2- } \\
\text { tailed) }\end{array}$ \\
\hline Pre-test and Post- test scores & -4.750 & 851 & .190 & -24.971 & 19 & .000 \\
\hline
\end{tabular}

The above-mentioned Table 2 is showing the results of the paired samples t-test, the P-value is showing the statistically significant difference because it is below 0.5 , in this way the null hypothesis is considered rejected. Besides, the relation between the independent variable and the dependent variable is also statistically significant. Consequently, it can be concluded that the use of multimedia glossing in teaching reading comprehension in an ESL context does improve the engineering students' reading comprehension ability. 
Semi-structured interviews were conducted to investigate the students' opinions on multimedia learning. Table 3 is showing the emerging themes derived through thematic analysis:

Table 3. Analysis of semi-structured interviews

\begin{tabular}{|l|l|l|}
\hline Emerging Themes & Percentage (\%) & Frequency \\
\hline Developing comprehension skills & 39.47 & 15 \\
\hline Vocabulary retention & 26.32 & 10 \\
\hline $\begin{array}{l}\text { Learning satisfaction and } \\
\text { motivation }\end{array}$ & 18.43 & 7 \\
\hline Mental image creation & 15.78 & 6 \\
\hline Total & 100 & 38 \\
\hline
\end{tabular}

The findings showed in the above-mentioned Table revealed that $39.47 \%$, with the frequency of 15 responses, the engineering students felt more comfortable in using multimedia glossing to improve their reading comprehension. Engineering students expressed they could effectively use the glossing available in multimedia in connecting information given in the texts provided. Students (participants of the study) expressed, they were able to recall the memorized words while attempting the test. Hence, it is proven that multimedia glossing in teaching and learning reading comprehension can be helpful for the students in recalling the vocabulary knowledge by memorization with an agreement of $26.32 \%$ or with a frequency of 10 responses. Students expressed that they could recall vocabulary knowledge while even they were interviewed. It shows students were able to memorize and store the information in short- and long-term memory and recalled them if needed to comprehend it. They were satisfied and motivated too as 7 responses confirmed it with $18.43 \%$.

Besides that, participants' scores showed they enhanced the ability to create mental images based on the information through multimedia learning, as demonstrated in table 3 , as $15.78 \%$ or with a frequency of 06 responses of the participants. Students stated they were able to comprehend the text by creating a mental image. This finding is supported by a response from an interview as students agreed that the use of textbooks hindered the process of

comprehension and creating mental images. Though, the application of multimedia glossing helped in learning reading comprehension and assisted them in imagining and building meaningful visualization of the text discussed in the ESL class. Besides, participants asserted that creating mental images was conceivable because of the assistance of multimedia glossing. These findings are clearly showing how the human brain works. According to dual coding theory, as found in the researchers conducted by (Mayer \& Moreno, 1996; Clark and Paivio, 1991; (1986); Wang and Li, 2019; Khalil and Elkhider, 2021).

The Language learners of today's' age are tech-savvy and they want always interesting and innovative methods of learning in their educational context. Thus, multimedia glossing helps in that, it makes learning interesting as well as innovative which enhances students' motivation. To enhance students' reading comprehension with the multimedia glossing needs the expertise to handle and design the multimedia mediated modules which can create a conducive environment for the ESL learners for learning reading comprehension. As the findings of the current study revealed that students felt motivated towards learning reading comprehension and they enjoyed learning with multimedia glossing, furthermore, it offers a fun, exciting, and interactive learning experience. Hence, the multimedia glossing remained overall effective in enhancing students" reading comprehension.

\section{Second Research Objective}

To investigate which multimedia gloss is more effective in helping the reading comprehension process of engineering students in ESL context.

Multimedia holds three glossing of media, and a test was needed to evaluate

the most effective glossing in enhancing reading comprehension of engineering students in the ESL context. Thus, the statistical test one-way ANOVA was carried out to analyse the null and alternate hypothesis, which are:

Null Hypothesis: There are no significant differences in the effects of three multimedia glossing used in helping the reading comprehension process of engineering students in the ESL context

Alternate hypothesis: There are significant differences in the effects of three multimedia glossing used in helping the reading comprehension process of engineering students in an ESL context. 
Table 4. Descriptive analysis multimedia glossing

\begin{tabular}{|l|l|l|l|l|l|}
\hline & $\mathbf{N}$ & Mean & $\begin{array}{l}\text { Std. } \\
\text { Deviation }\end{array}$ & Minimum & Maximum \\
\hline Videos & 20 & 6.45 & .605 & 5 & 7 \\
\hline Images & 20 & 5.06 & .887 & 4 & 7 \\
\hline Audios & 20 & 3.40 & 1.095 & 1 & 5 \\
\hline Total & 60 & 4.97 & 1.529 & 1 & 7 \\
\hline
\end{tabular}

As above mentioned, Table 4 is showing, the sample of this study $(n=20)$, the mean score of multimedia glossing's effectiveness. The video glossing scored higher $(\mathrm{m}=6.45, \mathrm{SD}=0.605, \mathrm{n}=20)$ compared to images glossing $(m=5.05, S D=0.887, n=20)$, and audio glossing $(m=3.40, S D=1.095, n=20)$.

Table 5. One way- ANOVA

\begin{tabular}{|l|l|l|l|l|l|}
\hline & Sum of squares & Df & Mean square & $\boldsymbol{F}$ & Sig. \\
\hline Between groups & 93.23 & 2 & 46.61 & 59.44 & .000 \\
\hline Within groups & 44.70 & 57 & .784 & & \\
\hline Total & 137.93 & 59 & & & \\
\hline
\end{tabular}

According to the findings, the p-value is $<.00001$; thus, the result is significant at $\mathrm{p}<.05$ and it is shown in Table 5. In this way, the null hypothesis is rejected. Hence, there is an adequate evidence-based on a $95 \%$ confidence interval to announce there are significant differences in the effectiveness of the multimedia glossing in the reading comprehension skills of the engineering students with $F(2,57)=.3 .15 ; p<0.05$. Consequently, the need for post hoc analysis is needed to identify the difference among the threemultimedia glossing used in the study.

Table 6. The Tukey Post Hoc Test analysis on multimedia glossing

\begin{tabular}{|c|c|c|c|c|}
\hline (I) GROUP & (J) GROUP & $\begin{array}{l}\text { Mean Difference } \\
(\mathrm{I}-\mathrm{J})\end{array}$ & Std. Error & Sig. \\
\hline Audio & $\begin{array}{l}\text { Picture } \\
\text { Video }\end{array}$ & $\begin{array}{l}-1.650^{*} \\
-3.050^{*}\end{array}$ & $\begin{array}{l}.280 \\
.280\end{array}$ & $\begin{array}{l}.000 \\
.000\end{array}$ \\
\hline Picture & $\begin{array}{l}\text { Audio } \\
\text { Video }\end{array}$ & $\begin{array}{l}1.650^{*} \\
1.400^{*}\end{array}$ & $\begin{array}{l}.280 \\
.280\end{array}$ & $\begin{array}{l}.000 \\
.000\end{array}$ \\
\hline Video & $\begin{array}{l}\text { Audio } \\
\text { Picture }\end{array}$ & $\begin{array}{l}3.050^{*} \\
1.400^{*}\end{array}$ & $\begin{array}{l}.280 \\
.280\end{array}$ & $\begin{array}{l}.000 \\
.000\end{array}$ \\
\hline
\end{tabular}

The findings and analysis based on the Tukey Post Hoc Test; there were statistically significant differences among three multimedia glossing i.e.: video, audio, and images, shown in Table 5 but it was the collective result. Therefore, the results of the Tukey Post Hoc test showed the differences among the group (video, audio, images) shown in Table 6. The findings revealed that there is a statistical difference in multimedia glossing picture and video individually in enhancing reading comprehension. However, there were no differences between audio and video multimedia, and audio and image multimedia on students' reading comprehension. Tukey Post Hoc Test showed there are significant differences between the audio group's mean scores and image and video group means' scores, whereas the mean scores of the audio group are smaller than the mean scores of the other groups.

Table 7. The homogenous subset of multimedia glossing

\begin{tabular}{|l|l|l|l|l|}
\hline \multirow{2}{*}{ GROUP } & \multirow{2}{*}{$\mathbf{N}$} & \multicolumn{3}{|l|}{ Subset for alpha = 0.05 } \\
\cline { 3 - 5 } & & 1 & 2 & 3 \\
\hline Audio & 20 & 3.40 & & \\
\hline Picture & 20 & & 5.05 & \\
\hline Video & 20 & & & 6.45 \\
\hline Sig. & & 1.000 & 1.000 & 1.000 \\
\hline
\end{tabular}


Means for groups in homogeneous subsets are displayed.

a. Uses Harmonic Mean Sample Size $=20.000$.

Table 7 on the homogenous subset is showing the mean score for the audio group (3.40)

is significantly smaller than the mean of the image group (5.05) and the video group's mean score (6.45). The ANOVA test analysis and Tukey Post Hoc Test displayed that the audio glossing of multimedia was observed as less effective than other multimedia glossing in enhancing reading comprehension skills of engineering students' reading comprehension. As discussed in the theory of multimedia learning by (Subaidi and Punan, 2020) the human mind cannot decode the information from many media elements in multimedia learning such as words, images, video, and audio in the chorus but rather the multimedia glossing should be selected purposely and should be organized to shape up a logical train of thought. Hence, most of the students didn't get many benefits from the audio multimedia glossing in learning reading comprehension in the current study.

\section{CONCLUSION}

The current study directs the optimistic influence of multimedia glossing integration into the ESL context in reading comprehension class of engineering students as the outcomes of the study are aligned with (Wang and Li, 2019) by putting more stress that multimedia gloss enhances learners' reading comprehension. Additionally, both theories also proved to be beneficial in enhancing the reading comprehension of the students by processing words, images, and videos into their learning as mentioned by (Mayer and Moreno, 1996). As discussed by (Khalil and Elkhider, 2021) the human mind has two processors thus, blending multimedia glossing can be beneficial to use those processors for enhancing reading comprehension performance and the current study proved that this blend worked in the enhancement of engineering students' reading comprehension performance. It is proven by the study that multimedia learning plays a significant role in scaffolding the engineering students' learning of reading comprehension. Students face many problems such as deciphering unfamiliar words, manipulating information required to answer the comprehension questions, and understanding the abstract ideas thus, all these problems can be solved with multimedia glossing assistance by integrating them into the lessons to let the students visualize the information easily presented in the text.

\section{Implications}

The current study has many suggestions, one of the suggestions is for teachers and university administrators to plan a multimedia integrated lessons/ modules/ program with a proper guideline to conduct English language classes. Besides that, the university community should incorporate multimedia glossing according to the need of the learners, learning, and context in their lessons as it will let them visualize difficult abstract information without difficulty. This recommendation is in line with (Moreno \& Mayer, 1997). Some of the guidelines that can be taken from the current research are designing and arranging the resources suitable to the learner's cognitive level and learners' needs, especially for engineering students, who are already into technology and know, how to use it. Besides, keeping into consideration the students' needs and interests too, teachers and designers of the courses must choose the materials for multimedia presentation purposefully and suitable as to avoid the failure of creating mental images in understanding the materials.

Besides, in the visualization process to integrate multimedia glossing for assisting university students in teaching reading comprehension, there should be a proper combination of multimedia while planning the lesson. The audiobooks are well-known and extensively used nowadays, but according to the current study, students were not much interested in audio as a teaching aid during the reading comprehension in the ESL class. Consequently, many studies on the use of audio, audio setting, and the appropriate types of audio when teaching reading is required to be conducted to find out the diversity of the findings and their implication in the ESL context.

\section{REFERENCES}

Ahmad Nasaruddin, N. S., \& Mohd Kamalludeen, R. (2020). A Case Study of How Malay ESL Learners Build Vocabulary Using Multimedia Technology. IIUM Journal of Educational Studies, 8(2), 112-130. https://doi.org/10.31436/ijes.v8i2.288

Alsofyani, A. H. (2019). Examining EFL Learners ' Reading Comprehension : The Impact of Metacognitive Strategies Discussion and Collaborative Learning within Multimedia E-book Dialogic Environments. In Dissertation - Doctoral (Issue May). 
Altrichter, H., Kemmis, S., Mctaggart, R., Zuber-skerritt, O., Altrichter, H., Mctaggart, R., \& Zuber-skerritt, O. (2005). The Learning Organization Emerald Article: The concept of action research The concept of action research. 2002. https://doi.org/10.1108/09696470210428840

Asher, S. R., Hymel, S., \& Wigfield, A. (1978). Influence of topic interest on children's reading comprehension. Journal of Literacy Research, 10(1), 35-47. https://doi.org/10.1080/10862967809547253

Bani-hamad, A. M. H., \& Abdullah, A. H. (2020). The Effect of Project-Based Learning to Improve the 21 st Century Skills among Emirati Secondary Students. January. https://doi.org/10.6007/IJARBSS/v9i12/6749

Berk, R. (2009). Multimedia teaching with video clips: TV, movies, YouTube, and mtvU in the college classroom. International Journal of Technology in Teaching \& Learning, 5(1).

Bhatti, A., Pathan, H., Tabieh, A., \& Hassan, A., (2020). Impact of Learner-learner Rapport on L2 Learning: A Study of Public Sector Universities in Sindh, Pakistan. The Asian EFL Journal,27 (4.6), 204-226.

Carroll, J. B. (1971). Defining Language comprehension: Some speculations. Language Comprehension and the Acquisition of Knowledge, 1-54.

Chiou, C. C., Tien, L. C., \& Lee, L. T. (2015). Effects on learning of multimedia animation combined with multidimensional concept maps. Computers and Education, 80, 211-223. https://doi.org/10.1016/j.compedu.2014.09.002

Clark, J. M., \& Paivio, A. (1991). Dual Coding Theory and Education. 3(3), 149-210.

Dedo, F. S., Hashim, H., Dedo, F. S., \& Hashim, H. (2020). Interactive ICT Language Games in Encouraging Active Learning among the Suburban ESL Learners Interactive ICT Language Games in Encouraging Active Learning among the Suburban ESL Learners. 9(12), 674-684. https://doi.org/10.6007/IJARBSS/v9-i12/6764

Derlina,, Aisyah,, Bukit, N., Sahyar,, Hassan, A., (2020). Blended Learning in English and English-Medium Physics Classes Using Augmented Reality, Edmodo, and Tinkercad Media. TESOL International Journal,15 (3), 111-136.

Farhat, P. A., \& Dzakiria, H. (2017). Pronunciation Barriers and Computer Assisted Language Learning (CALL): Coping the Demands of 21 st Century in Second Language Learning Classroom in Pakistan. International Journal of Research in English Education, 2(2), 53-62. https://doi.org/10.18869/acadpub.ijree.2.2.53

Fiorella, L., Vogel-Walcutt, J. J., \& Schatz, S. (2012). Applying the modality principle to real-time feedback and the acquisition of higher-order cognitive skills. Educational Technology Research and Development, 60(2), 223-238. https://doi.org/10.1007/s11423-011-9218-1

Hassan, A., Kazi, A.S., Shafqat, A., Ahmed, Z., (2020). The Impact of Process Writing on the Language and Attitude of Pakistani English Learners. The Asian EFL Journal,27 (4.3), 260-277.

Hassan, A., Mitchell, R., \& Buriro, H. A. (2020). Changes in uses of salutations in British English. International research journal of management, IT and social sciences, 7(1), 197-204.

Heo, M., \& Toomey, N. (2020). Learning with multimedia: The effects of gender, type of multimedia learning resources, and spatial ability. Computers and Education, 146(September 2019). https://doi.org/10.1016/j.compedu.2019.103747

Hilmi, M., \& Hamzah, B. (2020). INVESTIGATING THE USE OF COMPUTER-ASSISTED LANGUAGE INSTRUCTION : THE CASE OF PAKISTANI EFL TEACHERS INVESTIGATING THE USE OF COMPUTERASSISTED LANGUAGE INSTRUCTION : THE CASE OF PAKISTANI EFL TEACHERS. April.

Itmeizeh, M., \& Hassan, A. (2020). New Approaches to Teaching Critical Thinking Skills through a New EFL Curriculum. International Journal of Psychosocial Rehabilitation, 24(07).

K, L. A. (2020). Triggering Comprehensible Input through Multimedia: A Support to Enhance Learning Experience in the ESL Classroom. Journal of English Language Teachers' Interaction Forum, XI(September), 27-30.

Kakepoto, I., Mohd Omar, N. A., Boon, Y., \& Zafar Iqbal, S. M. (2012). Perspectives on Oral Communication Skills for Engineers in Engineering Profession of Pakistan. International Journal of Applied Linguistics \& English Literature, 1(5), 176-183. https://doi.org/10.7575/ijalel.v.1n.5p.176

Karthigesu, K., Mohamad, M., Karthigesu, K., \& Mohamad, M. (2020). Primary School Teachers 'Perceptions on the Integration of Interactive Whiteboard (IWB) during Reading Instructions Primary School Teachers 'Perceptions on the Integration of Interactive Whiteboard ( IWB ) during Reading Instructions. 1(2), 722-742. https://doi.org/10.6007/IJARBSS/v10-i2/6977

Khalil, M. K., \& Elkhider, I. A. (2021). Applying learning theories and instructional design models for effective instruction. 29605, 147-156. https://doi.org/10.1152/advan.00138.2015

Kirschner, P.A.1, P., B.2, M., \& S.2 Jarodzka, H. . 1. (2017). TOWARDS A COGNITIVE THEORY OF MULTIMEDIA ASSESSMENT ( CTMMA). 
LaBerge, D., \& Samuels, S. J. (1974). Toward a theory of automatic information processing in reading. Cognitive Psychology, 6(2), 293-323. https://doi.org/10.1016/0010-0285(74)90015-2

Liu, T. C., Lin, Y. C., Tsai, M. J., \& Paas, F. (2012). Split-attention and redundancy effects on mobile learning in physical environments. Computers and Education, 58(1), 172-180. https://doi.org/10.1016/j.compedu.2011.08.007

Mahboob, A. (2017). Chapter 5 English medium instruction in higher education in Pakistan: $P$ olicies, perceptions, problems, and possibilities. 2017, 71-92.

Mahmoudi, H. M., \& Hassan, A. CHALLENGES AND ISSUES OF LANGUAGE USE BETWEEN MONOLINGUAL AND MULTILINGUAL SOCIETIES. Dimension Journal of Humanities and Social Sciences, 1-19.

Manel, M., Hassan, A., \& Buriro, H. A. (2019). Learners' Attitudes towards Teachers' switching to the mother tongue (The Case of Secondary school learners in Algeria). Indonesian TESOL Journal, 1(1), 9-26.

Mayer, R. E., Heiser, J., \& Lonn, S. (2001). Cognitive constraints on multimedia learning: When presenting more material results in less understanding. Journal of Educational Psychology, 93(1), 187-198. https://doi.org/10.1037/0022-0663.93.1.187

Mayer, R. E., \& Mayer, R. E. (2010). Multimedia learning : Are we asking the right questions? Multimedia Learning : Are We Asking the Right Questions ? 1520. https://doi.org/10.1207/s15326985ep3201

Mayer, R. E., \& Moreno, R. (1996). A Cognitive Theory of Multimedia Learning: Implications for Design Principles. 1-10.

Mirza, Q., Pathan, H., Khatoon, S., Hassan, A., (2021). Digital Age and Reading habits: Empirical Evidence from Pakistani Engineering University. TESOL International Journal,16 (1), 210-136.

Moreno, R., \& Mayer, R. E. (1997). Cognitive Principles of Multimedia Learning: The Role of Modality and Contiguity. 91(2), 358-368.

Nawab, A. (2012). Is it the way to teach language the way we teach language? English language teaching in rural Pakistan. Academic Research International, 2(2), 696-705.

Paivio. (1999). mental states will be activation states of connectionist nodes or sets of. 1-9.

Rafiq, K. R. M., \& Hashim, H. (2018). Augmented Reality Game ( ARG ), 21 st century skills and ESL classroom. 1(1), 29-34.

Subaidi, M., \& Aziz, A. (2020). Indigenous Student's Perception of Multimedia Learning as an Approach for Enhancing Reading Comprehension Skills. 8-16. https://doi.org/10.31580/ojst.v3i1.1358

Subaidi, M., \& Punan, S. K. (2020). The Effectiveness of Multimedia Learning in Enhancing Reading Comprehension Among Indigenous Pupils. 11(June), 290-302.

Supriyatno, T., Susilawati, S., Hassan, A., (2020). E-learning development in improving students' critical thinking ability. Cypriot Journal of Educational Sciences, 15(5), 1099-1106. https://doi.org/10.18844/cjes.v15i5.5154

Us Saqlain, N., Shafqat, A., Hassan, A., (2020). Perception Analysis of English Language Teachers about Use of Contextualized Text for Teaching ESP. The Asian ESP Journal,16 (5.1), 275-299.

Wahab, N. A., Jaafar, R., Mustapha, R., Kamis, A., \& Affandi, N. M. (2017). The Effectiveness of Likes Method in Improving Reading Skills of Orang Asli The Effectiveness of Likes Method in Improving Reading Skills of Orang Asli Students. June, 73-80. https://doi.org/10.5539/ass.v13n6p74

Wang, L., \& Li, J. (2019). Development of an Innovative Dual-Coded Multimedia Application to Improve Reading Comprehension Students With Imagery Deficit. https://doi.org/10.1177/0735633117746748

Yunus, M., Yaacob, N., \& Suliman, A. (2020). The Use of Electronic Frog VLE in Assisting Reading Comprehension Activities. 8(3), 879-887. https://doi.org/10.13189/ujer.2020.080319 